\title{
Comparison of diagnostic values of haematological and inflammatory parameters in predicting COPD exacerbation
}

Aseih Hatefi Olaee1, Fariba Rezaeetalab ${ }^{2, \star}$, Nasim Lotfinejad ${ }^{3}$

${ }^{1}$ Internal Medicine Department, pulmonary ward, Fellowship of Gastroentestinal disease, Mashhad University of Medical sciences, Mashhad Iran 2Internal Medicine Department, pulmonary ward, Lung Diseases Research Center, Mashhad University of Medical sciences, Mashhad Iran

${ }^{3}$ Department of Research, Faculty of Medicine, Mashhad University of Medical sciences, Mashhad Iran

Abstract

English:

Objective: Many patients with chronic obstructive pulmonary disease (COPD) suffer from acute exacerbation. Acute exacerbation of COPD (AECOPD) is currently known as the most important leading cause of death worldwide. Therefore, recognising beneficial biomarkers in order to detect acute exacerbations promptly is crucial. This study aimed to evaluate the role of haematological and inflammatory parameters in the diagnosis of AECOPD.

Methods: This cross-sectional study was carried out on 63 patients with AECOPD, during exacerbation and stable period, and on 62 sex- and age-matched healthy controls. Haematological and inflammatory parameters were analysed, and other data were collected. Receiver operating characteristic (ROC) curve and the area under the curve (AUC) were used to evaluate the neutrophil-lymphocyte ratio (NLR), C-reactive protein (CRP) level, and mean platelet volume (MPV) in the diagnosis of patients with AECOPD.

Results: The predictive ability of NLR was higher than that of CRP and MPV. The cut-off value of NLR was 2.85, and the sensitivity and specificity for detecting AECOPD were $87 \%$ and $70 \%$, respectively (AUC $=0.84, P<0.001)$. NLR values positively correlated with the CRP level, erythrocyte sedimentation rate (ESR) and platelet (PLT) count $(r=0.44, P=0.001 ; r=0.31$, $P=0.020$; and $r=0.32, P=0.010$, respectively) and negatively correlated with the albumin level and MPV in patients with AECOPD $(r=-0.31, P=0.049$ and $r=-0.27, P=0.040)$.

Conclusion: NLRs and CRP levels were both increased in patients with AECOPD, and they are both available and beneficial markers in the prompt detection of AECOPD. Further studies should be performed to underpin the diagnostic and prognostic values of haematological and inflammatory biomarkers in patients with COPD.

\section{Compararea valorilor diagnostice ale parametrilor hematologici și inflamatori în prezicerea exacerbării BPOC}

\section{Romanian:}

Obiectiv: Mulți pacienți cu boală pulmonară obstructivă cronică suferă de exacerbare acută. Exacerbarea acută a bolii pulmonare obstructive cronice (AECOPD) este cunoscută în prezent ca fiind cea mai importantă cauză de deces la nivel mondial. Prin urmare, recunoașterea biomarkerilor benefici pentru a detecta prompt exacerbările acute este crucială. Acest studiu a avut ca scop evaluarea rolului parametrilor hematologici și inflamatori în diagnosticul AECOPD.

Metoda: Acest studiu transversal a fost efectuat pe 63 de pacienti cu AECOPD, în timpul exacerbării si perioadei stabile, și 62 de subiecti control sănătosi, potriviti pentru sex și vârstă. Au fost analizați parametrii hematologici și inflamatori și au fost colectate alte date. Curba caracteristicilor de functionare a receptorului (ROC) și zona de sub curbă (ASC) au fost utilizate pentru a evalua raportul limfocitelor neutrofile (NLR), proteina C reactivă (CRP) și volumul mediu de trombocite (MPV) în diagnosticul pacienților cU AECOPD.

*Corresponding author: Fariba Rezaeetalab

E-mail: rezaitalabf@mums.ac.ir; tel.: +98915503348 
Rezultate: Capacitatea predictivă a NLR a fost mai mare decât CRP și MPV. Valoarea limită a NLR a fost de 2.85, iar sensibilitatea și specificitatea pentru detectarea AECOPD au fost de $87 \%$ și respectiv $70 \%$ (ASC $=0.84, P<0.001$ ). Valorile NLR s-au corelat pozitiv cu CRP, ESR și numărul de trombocite ( $r=0.44, P=0.001 ; r=0.31, P=0.020 ;$ și $r=0.32$, respectiv $P=0.010)$ și $s$-au corelat negativ cu albumina și MPV la pacienții cu AECOPD $(r=-0.31, P=0.049$ și $r=-0.27, P=0.040)$.

Concluzie: NLR și CRP au fost ambele crescute la pacienții cu AECOPD și sunt ambii markeri disponibili și benefici în detectarea promptă a AECOPD. Ar trebui efectuate studii suplimentare pentru a susține valorile de diagnostic și prognostic ale biomarkerilor hematologici și inflamatori la pacienții cu BPOC.

Cuvinte-cheie

acut • exacerbare • boală pulmonară obstructivă cronică • raport neutrofil-limfocit • proteina C-reactiva

\section{Introduction}

Chronic obstructive pulmonary disease (COPD) is a prevalent progressive inflammatory disease, described as chronic airflow limitation which is not completely reversible. Acute exacerbation of COPD (AECOPD) is known as a sudden deterioration of the respiratory system, which lasts for several days and frequently requires further and urgent treatment (1). Airway inflammation is increased during COPD exacerbation resulting in hyperinflation, reduced expiratory airflow and worsening gas exchange $(2,3)$. During the course of illness, most patients with COPD experience acute exacerbations that lead to hospitalisation, death and morbidity.

There are many biomarkers available to predict the outcome in patients with AECOPD, requiring various tests, yet no specific one has been generally acceptable $(4,5)$. It has been proposed that decreased lung function due to COPD is associated with an increased neutrophil count in the sputum and airway structures that has a significant relationship with disease severity $(6,7)$. Inflammatory cells include neutrophils and lymphocytes which are routinely tested, and the neutrophil-lymphocyte ratio (NLR) is known as a trustworthy marker for inflammatory conditions $(8,9)$. In addition, platelet (PLT) count plays an important role in COPD inflammations (10). Size and activity of PLTs are reflected in the mean platelet volume (MPV); hence, a changing pattern of PLT activity in COPD affects this parameter (11-13). C-reactive protein (CRP) is another marker of inflammation that associates with decreased lung function $(14,15)$. The aim of the current study was to investigate the value of haematologic indices in patients with stable COPD and AECOPD and compare them with healthy controls.

\section{Material and methods}

\section{Study design and population}

This cross-sectional study was conducted on 63 consecutive patients with AECOPD attending the Mashhad University of Medical Sciences during 2018. The control group included
62 exactly age- and sex-matched healthy individuals without asthma, COPD, history of haematologic diseases, liver diseases, drugs effecting PLT numbers (e.g. Non steroidal Anti inflammatory Drugs (NSAIDs) and aspirin), kidney and cardiac diseases, diabetes, malignancies and cigarette smoking. The current study was approved by the local ethics committee of Mashhad University of Medical Sciences, which complied with the Declaration of Helsinki, and written informed consent was obtained from all the participants. COPD was confirmed by using spirometry (Multifunctional Spirometer HI-801; Chest MI Inc., Tokyo, Japan) with the determination of forced expiratory volume in 1 second (FEV1) according Global Initiative for Chronic Obstructive Lung disease (GOLD) criteria 2019 and assess airflow obstruction to classify COPD severity based on fixed cut-off points of FEV1/ Forced vital capacity (FVC) $<70 \%$. FVC and FEV1/FVC were measured three times by an experienced single operator, and the maximum measurements were selected. Each recorded result was expressed as a percentage of the predicted value for that parameter. Exacerbations were defined as an increase in major symptoms including dyspnoea, sputum volume, sputum colour compared with the routine, acute hypercapnia, hypoxaemia and acute respiratory acidosis state (16). Exclusion criteria included known cases of carcinoma, active tuberculosis, diabetes mellitus, hypertension, collagen vascular diseases and anaemia.

\section{Laboratory investigations}

Following thorough history and physical exams, $5 \mathrm{cc}$ blood was obtained during the first few hours of admission before antibiotic therapy for complete blood cell count (CBC) including MPV, PLT count, white blood cell (WBC) count and NLR using AutoAnalyzer (Sysmex XE-2100, Sysmex Corporation, Kobe, Japan). Blood gas (venous blood sample) was evaluated at the same time. CRP level was measured with the DIALAB® Kit (which is obtained from a manufacturer and distributor of Diagnostics and Laboratory Equipment, Vienna, Austria). The aforementioned laboratory tests were also taken from the control group. CBC-including MPV, 
erythrocyte sedimentation rate (ESR) and CRP and albumin levels-was measured in the stable phase of COPD, at least 4 weeks after exacerbation.

\section{Statistical analysis}

Qualitative data were presented as frequencies and percentages, while quantitative variables as means \pm standard deviation $( \pm S D)$. The chi-squared/Fisher's exact test was performed to compare the outcomes between the two study groups. The Student's $t$-test was used in order to compare the parameters between patients with stable COPD and controls, while a paired $t$-test was performed to compare the parameters between patients with COPD exacerbation and stable COPD. Pearson/Spearman's correlation test was performed to search the correlation between continuous variables. The receiver operating characteristic (ROC) curves for NLR, CRP and MPV were constructed in discrimination of subjects with AECOPD from those with stable COPD, and the area under the curve (AUC) was obtained to determine the optimal cut-off values. All analyses were conducted using SPSS, version 16, and $P$-value $<0.050$ was accepted as statistically significant in our study.

\section{Results}

We recruited 63 patients with COPD, with a mean age of $68.57 \pm 11.06$ years in this study: $35(55.6 \%)$ of them were women and $28(44.4 \%)$ were men. In addition, 62 healthy individuals with a mean age of $67.90 \pm 10.81$ years constituted the control group. A total of 33 (52.4\%) patients with COPD were active or passive cigarette smokers, and the mean pack-years of smoking was $22.99 \pm 43$. Twentynine $(46 \%)$ patients had biomass exposure and were used to bread-cooking, with a mean duration of $19.9 \pm 21.45$ months. A total of 16 patients used waterpipe tobacco and 31 were opium addicts. During the study period, $4(6.3 \%)$ of the patients with COPD died, and 52 of all patients with COPD became clinically stable.

The mean \pm SD of indices in arterial blood gas samples was as follows: $\mathrm{pH}=7.35 \pm 0.07 ; \mathrm{PaCO}_{2}=58.03 \pm 18.31 \mathrm{~mm}$ $\mathrm{Hg} ; \mathrm{PaO}_{2}=59.26 \pm 15.3 \mathrm{~mm} \mathrm{Hg}$. The mean of spirometric parameters including FVC, FEV1 and FEV1/FVC was $66.22 \pm 20,61.61 \pm 19.4$ and $66.80 \pm 15.10$, respectively (Table 1). Table 2 illustrates the comparison of laboratory parameters between patients with stable COPD and the control group. WBC, haematocrit (HCT), mean corpuscular volume (MCV), MPV, red cell distribution width (RDW), neutrophil counts, NLR, lymphocyte count and CRP levels were statistically significant among the two groups. Patients with stable COPD had statistically higher levels of WBC, HCT, MCV, RDW, neutrophil count,
Table 1. Pulmonary function parameters of patients with AECOPD

\begin{tabular}{lc}
\hline Variables & Mean \pm SD \\
\hline $\mathrm{pH}$ & $7.35 \pm 0.07$ \\
$\mathrm{PaCO}_{2}$ & $58.03 \pm 18.31 \mathrm{mmHg}$ \\
$\mathrm{PaO}_{2}$ & $59.26 \pm 15.3 \mathrm{mmHg}$ \\
$\mathrm{FEV} 1$ (L/s) & $61.61 \pm 19.4$ \\
$\mathrm{FEV} 1 / \mathrm{FVC}(\%)$ & $66.8 \pm 15.1$ \\
$\mathrm{FVC}(\mathrm{L} / \mathrm{s})$ & $66.22 \pm 20$ \\
\hline
\end{tabular}

AECOPD, acute exacerbation of chronic obstructive pulmonary disease; FEV1, forced expiratory volume in 1 second; FVC, forced vital capacity.

Table 2. Comparison of laboratory data of subjects in the stable phase of COPD and healthy controls

\begin{tabular}{|c|c|c|c|}
\hline \multirow{2}{*}{ Variables } & Stable COPD & Healthy control & \multirow{2}{*}{$P$-value } \\
\hline & Mean \pm SD & Mean \pm SD & \\
\hline WBC, $\underline{x} 10^{9} / \mathrm{L}$ & $8.04 \pm 2.83$ & $6.77 \pm 1.45$ & 0.002 \\
\hline $\mathrm{Hb}, \mathrm{g} / \mathrm{dL}$ & $14.7 \pm 2.5$ & $13.98 \pm 1.58$ & 0.610 \\
\hline HCT (\%) & $43.84 \pm 7$ & $41.62 \pm 3.89$ & 0.030 \\
\hline $\mathrm{MCV}(\mathrm{fL})$ & $89.05 \pm 5.56$ & $86.46 \pm 4.45$ & 0.005 \\
\hline $\mathrm{MCH}(\mathrm{pg})$ & $28.79 \pm 2.56$ & $29.03 \pm 2.18$ & 0.580 \\
\hline $\mathrm{PLT}, \underline{x} 10^{9} / \mathrm{L}$ & $235 \pm 69.19$ & $230.19 \pm 59.67$ & 0.650 \\
\hline MPV (fL) & $9.7 \pm 0.9$ & $10.1 \pm 1.2$ & 0.001 \\
\hline PDW (fL) & $13.7 \pm 2.24$ & $13.93 \pm 2.33$ & 0.060 \\
\hline RDW, \% & $15.23 \pm 2.75$ & $13.96 \pm 3.34$ & 0.020 \\
\hline Neutrophils, $\underline{x} 10^{9} / \mathrm{L}$ & $5.33 \pm 1.99$ & $3.97 \pm 1.33$ & $\leq 100.0$ \\
\hline Lymphocytes, $\underline{x} 10^{9} / \mathrm{L}$ & $1.93 \pm 0.79$ & $2.17 \pm 0.58$ & 0.040 \\
\hline NLR & $3.92 \pm 4.83$ & $1.96 \pm 0.82$ & 0.002 \\
\hline $\mathrm{CRP}(\mathrm{mg} / \mathrm{L})$ & $16.85 \pm 30.04$ & $2.21 \pm 3.87$ & $\leq 100.0$ \\
\hline $\mathrm{ESR}(\mathrm{mm} / \mathrm{h})$ & $18.08 \pm 22.1$ & $14.81 \pm 11.43$ & 0.380 \\
\hline
\end{tabular}

Data are presented as mean \pm SD.

COPD, chronic obstructive pulmonary disease; CRP, C-reactive protein; $\mathrm{ESR}$, erythrocyte sedimentation rate; $\mathrm{HCT}$, haematocrit; $\mathrm{Hb}$, haemoglobin; $\mathrm{MCH}$, mean corpuscular haemoglobin; MCV, mean corpuscular volume; MPV, mean platelet volume; NLR, neutrophil-to-lymphocyte ratio; PLT, platelet; PDW, platelet distribution width; RDW, red cell distribution width; WBC, white blood cell count.

NLR and CRP compared to the controls $(P=0.002$, $P=0.030, P=0.005, P=0.020, P<0.001, P=0.002$ and $P<0.001$, respectively). MPV and lymphocyte count were significantly lower in patients with stable COPD than controls $(P=0.020$ and $P=0.040)$. The PLT count was slightly increased in patients with stable COPD, but the difference was not statistically significant compared to the controls $(P=0.650)$.

A total of 52 individuals with COPD exacerbation were evaluated after 4 weeks, during their stable phase. As shown in Table 3, patients with AECOPD had significantly higher levels of WBC, neutrophil count, NLR and CRP than those in their stable period $(P<0.001)$. Patients 
Table 3. Laboratory data of patients with stable COPD and AECOPD

\begin{tabular}{|c|c|c|c|}
\hline & AECOPD & Stable COPD & \\
\hline Variables & Mean \pm SD & Mean \pm SD & $P$-value \\
\hline WBC, $\times 10^{9} / \mathrm{L}$ & $11.91 \pm 5.52$ & $7.82 \pm 1.99$ & $<100.0$ \\
\hline Neutrophils, $\times 10^{9} / \mathrm{L}$ & $9.87 \pm 5.34$ & $5.02 \pm 1.9$ & $<100.0$ \\
\hline Lymphocytes, $\times 10^{9} / \mathrm{L}$ & $1.38 \pm 0.69$ & $1.97 \pm 0.80$ & $<100.0$ \\
\hline NLR & $9.19 \pm 7.26$ & $3.63 \pm 4.96$ & $<100.0$ \\
\hline $\mathrm{Hb}, \mathrm{g} / \mathrm{dL}$ & $14.07 \pm 2.31$ & $13.95 \pm 2.54$ & 0.580 \\
\hline HCT (\%) & $43.14 \pm 7.08$ & $42.91 \pm 6.67$ & 0.700 \\
\hline $\mathrm{MCH}(p g)$ & $28.87 \pm 2.63$ & $28.68 \pm 2.75$ & 0.320 \\
\hline RDW (\%) & $15.15 \pm 2.62$ & $15.22 \pm 2.85$ & 0.760 \\
\hline $\mathrm{PLT}, \times 10^{9} / \mathrm{L}$ & $259.27 \pm 118.83$ & $243.23 \pm 70.62$ & 0.300 \\
\hline MPV, fL & $9.97 \pm 0.97$ & $9.82 \pm 1.21$ & 0.270 \\
\hline PDW, fL & $13.07 \pm 1.91$ & $12.89 \pm 2.34$ & 0.530 \\
\hline CRP (mg/L) & $40.83 \pm 54.35$ & $9.65 \pm 12.46$ & $<100.0$ \\
\hline $\mathrm{ESR}(\mathrm{mm} / \mathrm{h})$ & $20.88 \pm 20.19$ & $17.46 \pm 18.46$ & 0.380 \\
\hline Albumin (g/dL) & $3.74 \pm 0.52$ & $4.1 \pm 0.37$ & 0.004 \\
\hline
\end{tabular}

Data are presented as mean \pm SD .

AECOPD, acute exacerbation of chronic obstructive pulmonary disease COPD, chronic obstructive pulmonary disease; CRP, C-reactive protein; $\mathrm{ESR}$, erythrocyte sedimentation rate; $\mathrm{HCT}$, haematocrit; $\mathrm{Hb}$, haemoglobin; $\mathrm{MCH}$, mean corpuscular haemoglobin; MPV, mean platelet volume; NLR, neutrophil-to-lymphocyte ratio; PLT, platelet; PDW, platelet distribution width RDW, red cell distribution width; WBC, white blood cell count.

with AECOPD had lower levels of lymphocyte count and albumin compared to the other group $(P<0.001$ and $P=0.004$ ).

ROC curve analysis was drawn for NLR, CRP levels and $M P V$ in order to differentiate AECOPD and the stable phase. It was demonstrated that NLR and CRP levels had a significant diagnostic value in discriminating AECOPD from stable COPD (AUC $=0.84, P<0.001$ and $A U C=0.79$, $P<0.001$, respectively). ROC curve analysis for NLR to predict AECOPD showed a cut-off of 2.85, AUC of 0.84 , sensitivity of $87 \%$ and specificity of $70 \%$ (Figure 1). This predictive ability was more than that of CRP, while MPV was not statistically significant in detecting AECOPD. The predictive accuracy of the aforementioned biomarkers is listed in Table 4.

There was a significant positive correlation between NLR and CRP level, ESR and PLT count among patients with AECOPD $(r=0.44, P=0.001 ; r=0.31, P=0.020$ and $r=0.32, P=0.010$, respectively). In contrast, NLR was negatively correlated with albumin level and MPV $(r=-0.31, P=0.049$ and $r=-0.27, P=0.040)$. There was no correlation between NLR and $\mathrm{PCO}_{2}, \mathrm{PO}_{2}$ and $\mathrm{SaO}_{2}$ ( $P=0.180, P=0.920$ and $P=0.320$, respectively). Data are demonstrated in Table 5.

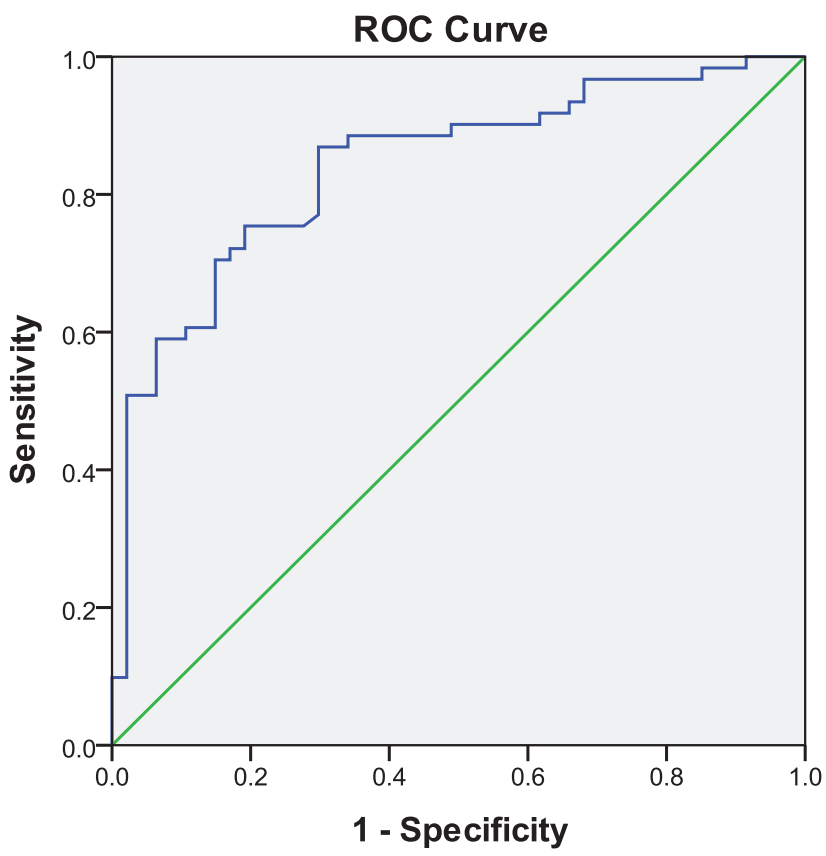

Figure 1. Receiver operator characteristic curve for distinguishing results of patients with AECOPD and stable COPD for C-reactive protein (CRP), mean platelet volume (MPV) and neutrophil-tolymphocyte ratio (NLR). AECOPD, acute exacerbation of chronic obstructive pulmonary disease; COPD, chronic obstructive pulmonary disease.

Table 4. Prognostic accuracy of the NLR, CRP level and MPV for differentiating AECOPD from the stable COPD

\begin{tabular}{lcc}
\hline Variables & AUC & $P$-value \\
\hline NLR & 0.84 & $<100.0$ \\
CRP & 0.79 & $<100.0$ \\
MPV & 0.54 & 0.470 \\
\hline
\end{tabular}

AUC, area under the curve; AECOPD, acute exacerbation of chronic obstructive pulmonary disease; COPD, chronic obstructive pulmonary disease; CRP, C-reactive protein; MPV, mean platelet volume; NLR, neutrophil-tolymphocyte ratio.

\section{Discussion}

AECOPD has a major reversed outcome in the prognosis of the patients including morbidity and mortality. Therefore, prompt detection of acute exacerbations accompanied by necessary treatments leads to improvement of the prognosis and reducing the hospitalisation risk (17-19). Finding a reliable marker that can precisely evaluate the diagnosis of AECOPD is considerably helpful for patient management. In the current study, we found that NLR and CRP levels were significant for the diagnosis of AECOPD. 
Table 5. Correlation of NLR with other laboratory parameters in patients with AECOPD

\begin{tabular}{|c|c|c|c|c|c|c|c|c|c|}
\hline Variables & CRP & ESR & Albumin & MPV & $\mathrm{pH}$ & PLT count & $\mathrm{PCO}_{2}$ & $\mathrm{PO}_{2}$ & $\mathrm{SPO}_{2}$ \\
\hline \multicolumn{10}{|l|}{ Number } \\
\hline$r$ (Pearson correlation) & 0.44 & 0.31 & -0.31 & -0.27 & 0.26 & 0.32 & -0.18 & -0.01 & 0.14 \\
\hline \multicolumn{10}{|l|}{$r$ (Spearman correlation) } \\
\hline$P$-value & 0.001 & 0.020 & 0.049 & 0.040 & 0.040 & 0.010 & 0.180 & 0.920 & 0.320 \\
\hline
\end{tabular}

AECOPD, acute exacerbation of chronic obstructive pulmonary disease; CRP, C-reactive protein; ESR, erythrocyte sedimentation rate; MPV, mean platelet volume; NLR, neutrophil-to-lymphocyte ratio; PLT, platelet.

They were significantly higher in both COPD groups than in the controls, and they were found to be higher in AECOPD compared to those in the stable phase. In addition, NLR was found to have a higher sensitivity and specificity for detecting AECOPD than the CRP level. According to our findings, NLR positively correlated with the CRP level in patients with AECOPD, and NLR and CRP levels were significantly higher during the exacerbation period than the stable phase. This study also revealed a positive relationship between NLR and ESR, PLT count and $\mathrm{pH}$. NLR had a negative correlation with MPV and serum albumin level. On the other hand, NLR showed no meaningful relationship with other haematological indices, FEV1, FEV1/FVC, hospitalisation period, $\mathrm{SPO}_{2}$ and $\mathrm{PO}_{2} \%$.

Our results were consistent with the existing literature regarding NLR as a helpful marker for the diagnosis and prognosis of AECOPD. According to the ROC curve analysis, the best cut-off value for NLR was 2.85 for detecting AECOPD, which was lower than that of other studies $(9,20)$. In a study performed by In et al. (21), NLR was found to be positively correlated with ESR and CRP levels and negatively correlated with FVC and FEV1. They also concluded that, with an NLR cut-off of 3.34 , the sensitivity and specificity for the diagnosis of AECOPD were $78.7 \%$ and $73.2 \%$, respectively (AUC 0.863, $P<0.001$ ). In another study, Gunay et al. (22) compared patients with AECOPD, patients with stable COPD and healthy controls and found that NLR of the patients with stable COPD was significantly higher than that of the healthy controls. Subsequently, NLR increased even more during the exacerbation period. It has been established that NLR levels have a positive correlation with CRP levels during the exacerbation period.

Both MPV and PDW are markers of PLT activation (23). Increased MPV associates with diabetes mellitus, obesity, hypercholesterolaemia and cardiovascular and cerebrovascular diseases, while decreased levels of MPV were seen in rheumatologic diseases such as rheumatoid arthritis (11, 24). Agapakis et al. (25) demonstrated that MPV was lower in patients with AECOPD than in patients with stable COPD and healthy controls. Decreased MPV levels concomitant with an increase in CRP and WBC levels have been also identified among patients with AECOPD in many studies that were in line with the results of our study $(12,25-27)$. On the contrary, increased MPV levels were also reported in patients with COPD, due to PLT activation triggered by hypoxia $(28,29)$. PDW reveals PLT volume heterogeneity (30), which was not significantly different between our study groups. A study conducted by Steiropoulos et al. (13) confirmed our findings, as they also concluded that there was no difference regarding PDW between patients with COPD and controls.

In a study performed by Wang et al. (26), patients with COPD showed higher levels of WBC counts during the exacerbation period compared to the stable phase, which was similar to our results. According to the literature, the prevalence of anaemia in patients with COPD varies from $7.5 \%$ to $34 \%$. However, only a few studies have proven a relationship between anaemia and COPD, and the incidence of anaemia has remained unknown (31). We found no significant relationship between haemoglobin and COPD in our study. Low serum albumin level predicts poor prognosis and higher mortality rates, while it is identified as a risk factor of COPD exacerbation $(32,33)$. Meanwhile, Shafiek et al. (34) demonstrated no difference in serum albumin levels between the survivors and non-survivors of COPD. Serum albumin level was significantly lower during the exacerbation period compared to the stable phase in our study.

\section{Conclusion}

In conclusion, we showed that NLR and CRP levels were markers of benefit for detecting exacerbated COPD, and they were both higher in patients with stable COPD than in controls and also higher in the exacerbation period than in the stable phase. On the basis of the current results, a cut-off value of 2.85 was proposed for NLR. Haematological parameters that are available and inexpensive to perform were beneficial in early detection of AECOPD in this study. These results justify further studies with larger sample sizes to address the role of haematological and inflammatory parameters in determining hospital admission, severity and prognosis of exacerbated COPD. 


\section{Acknowledgement}

This study was financially supported by the Research Deputy of Mashhad University of Medical Sciences, Mashhad, Iran.

\section{Conflict of interest}

The authors declare that they have no conflict of interest.

\section{References}

1. Mirza S, Clay RD, Koslow MA, Scanlon PD. COPD guidelines: A review of the 2018 GOLD Report. Mayo Clin Proc. 2018;93(10): 1488-1502.

2. Barbu C, lordache M, Man MG. Inflammation in COPD: Pathogenesis, local and systemic effects. Rom J Morphol Embryol. 2011;52(1): 21-27.

3. Wouters EF, Groenewegen KH, Dentener MA, Vernooy JH. Systemic inflammation in chronic obstructive pulmonary disease: The role of exacerbations. Proc Am Thorac Soc. 2007;4(8): 626-634.

4. Koutsokera A, Stolz D, Loukides S, Kostikas K. Systemic biomarkers in exacerbations of COPD: The evolving clinical challenge. Chest. 2012;141(2): 396-3405.

5. Singanayagam A, Schembri S, Chalmers JD. Predictors of mortality in hospitalized adults with acute exacerbation of chronic obstructive pulmonary disease. Ann Am Thorac Soc. 2013;10(2): 81-89.

6. Hoenderdos $\mathrm{K}$, Condliffe A. The neutrophil in chronic obstructive pulmonary disease. Am J Respir Cell Mol Biol. 2013;48(5): 531-539.

7. Barnes PJ. Inflammatory mechanisms in patients with chronic obstructive pulmonary disease. J Allergy Clin Immunol. 2016;138(1): 16-27.

8. Zhou X, Li Q, Zhou X. Exacerbation of chronic obstructive pulmonary disease. Cell Biochem Biophys. 2015;73(2): 349-355.

9. Pascual-Gonzalez Y, Lopez-Sanchez M, Dorca J, Santos S. Defining the role of neutrophil-to-lymphocyte ratio in COPD: A systematic literature review. Int J Chron Obstruct Pulmon Dis. 2018;13: 3651-3662.

10. Bialas AJ, Pedone C, Piotrowski WJ, Incalzi RA. Platelet distribution width as a prognostic factor in patients with COPD - pilot study. Int J Chron Obstruct Pulmon Dis. 2017;12: 2261-2267.

11. Chu SG, Becker RC, Berger PB, Bhatt DL, Eikelboom JW, Konkle B, et al. Mean platelet volume as a predictor of cardiovascular risk: A systematic review and meta-analysis. J Thromb Haemost. 2010;8(1): 148-156.
12. Biljak VR, Pancirov D, Cepelak I, Popovic-Grle S, Stjepanovic G, Grubisic TZ. Platelet count, mean platelet volume and smoking status in stable chronic obstructive pulmonary disease. Platelets. 2011;22(6): 466-470.

13. Steiropoulos P, Papanas N, Nena E, Xanthoudaki M, Goula T, Froudarakis $\mathrm{M}$, et al. Mean platelet volume and platelet distribution width in patients with chronic obstructive pulmonary disease: The role of comorbidities. Angiology. 2013;64(7): 535-539.

14. Kony S, Zureik M, Driss F, Neukirch C, Leynaert B, Neukirch F. Association of bronchial hyperresponsiveness and lung function with C-reactive protein (CRP): A population based study. Thorax. 2004;59(10): 892-896.

15. Dentener MA, Creutzberg EC, Schols AM, Mantovani $A$, Veer CV, Buurman WA, et al. Systemic anti-inflammatory mediators in COPD: Increase in soluble interleukin 1 receptor II during treatment of exacerbations. Thorax. 2001;56(9): 721-726.

16. Burge S, Wedzicha JA. COPD exacerbations: Definitions and classifications. Eur Respir J. 2003;21(41 suppl): 46s-53s.

17. Wilkinson TM, Donaldson GC, Hurst JR, Seemungal TA, Wedzicha JA. Early therapy improves outcomes of exacerbations of chronic obstructive pulmonary disease. Am J Respir Crit Care Med. 2004;169(12): 1298-1303.

18. Rodriguez-Roisin R. COPD exacerbations 5: Management. Thorax. 2006;61(6): 535-544.

19. Soler-Cataluna JJ, Martinez-Garcia MA, Sanchez PR, Salcedo E, Navarro M, Ochando R. Severe acute exacerbations and mortality in patients with chronic obstructive pulmonary disease. Thorax. 2005;60(11): 925-931.

20. Tanriverdi H, Ornek T, Erboy F, Altinsoy B, Uygur F, Atalay F, et al. Comparison of diagnostic values of procalcitonin, C-reactive protein and blood neutrophil/lymphocyte ratio levels in predicting bacterial infection in hospitalized patients with acute exacerbations of COPD. Wien Klin Wochenschr. 2015;127(19): 756-763.

21. In $E$, Kuluozturk $M$, Oner $O$, Deveci $F$. The importance of neutrophil-to-lymphocyte ratio in chronic obstructive pulmonary disease. Turk Thorac J. 2016;17(2): 41-46.

22. Gunay E, Ulasli SS, Akar O, Ahsen A, Gunay S, Koyuncu T, et al. Neutrophil-to-lymphocyte ratio in chronic obstructive pulmonary disease: A retrospective study. Inflammation. 2014;37(2): 374-380.

23. Vagdatli E, Gounari E, Lazaridou E, Katsibourlia E, Tsikopoulou F, Labrianou I. Platelet distribution width: A simple, practical and specific marker of activation of coagulation. Hippokratia. 2010;14(1): 28-32.

24. Gasparyan AY, Ayvazyan L, Mikhailidis DP, Kitas GD. Mean platelet volume: A link between thrombosis and inflammation? Curr Pharm Des. 2011;17(1): 47-58.

25. Agapakis DI, Massa EV, Hantzis I, Maraslis S, Alexiou E, Imprialos KP, et al. The role of mean platelet volume in chronic 
obstructive pulmonary disease exacerbation. Respir Care. 2016;61(1): 44-49.

26. Wang RT, Li JY, Cao ZG, Li Y. Mean platelet volume is decreased during an acute exacerbation of chronic obstructive pulmonary disease. Respirology. 2013;18(8): 1244-1248.

27. Ulasli SS, Ozyurek BA, Yilmaz EB, Ulubay G. Mean platelet volume as an inflammatory marker in acute exacerbation of chronic obstructive pulmonary disease. Pol Arch Med Wewn. 2012;122(6): 284-290.

28. Makhlouf HA, Sadek SH, Nafady AA. Platelet function in diabetic and nondiabetic patients with chronic obstructive pulmonary disease: A case control study. Clin Respir J. 2018;12(1): 48-56.

29. Bansal R, Gupta HL, Goel A, Yadav M. Association of increased platelet volume in patients of chronic obstructive pulmonary disease: Clinical implications. J Indian Acad Clin Med. 2002;3(2): 169-172.
30. Bessman JD, Williams LJ, Gilmer PR, Jr. Platelet size in health and hematologic disease. Am J Clin Pathol. 1982;78(2): 150-153.

31. Yohannes AM, Ershler WB. Anemia in COPD: A systematic review of the prevalence, quality of life, and mortality. Respir Care. 2011;56(5): 644-652.

32. Gunen H, Hacievliyagil SS, Kosar F, Mutlu LC, Gulbas G, Pehlivan E, et al. Factors affecting survival of hospitalised patients with COPD. Eur Respir J. 2005;26(2): 234-241.

33. Groenewegen KH, Schols AM, Wouters EF. Mortality and mortality-related factors after hospitalization for acute exacerbation of COPD. Chest. 2003;124(2): 459-467.

34. Shafiek H, Abd-elwahab N, Baddour M, Degady A, El-hoffy M. Outcome predictors of severe acute exacerbation of chronic obstructive pulmonary disease: Role of inflammatory biomarkers. Int J Respir Pulm Med. 2016;3(2): 047. 